parasites which have been found on a few occasions, bodies in the lumen of the appendix may be classified under the following heads, which I give in the order of frequency of their occurrence: (1) fæcal moulds as defined above; (2) enteroliths with or without a foreign body as a nucleus; (3) gall-stones ; and (4) true foreign bodies. Cork.

\section{A CASE OF APPENDICITIS EXCITED BY A CLOVE, THE APPENDIX BEING THE SOLE VISCUS IN A HERNIAL SAC.}

BY W. HAL BARNETT, M.B., B.S. LOND., AND

J. W. SCOTT MACFIE, B.A., B.Sc., M.B., B.CH. EDIN., HOUSE SURGEONS TO THE RADCLIFFE INFIRMARY AND COUNTY HOSPITAL, OXFORD.

THE patient who is the subject of this note was a man 58 years of age, who was admitted to the Radcliffe Infirmary and County Hospital on May 5th, 1907, complaining of a tense and painful swelling in his right groin. The history of the case was as follows. For quite 20 years the patient had suffered from a rupture in the right inguinal region, which he controlled by the use of a truss during the daytime. He was never inconvenienced by this and when, as occasionally happened, the bowel came down he was easily able to return it. One morning, however, about a week before his admission, he awoke to find that a swelling had come down, which, unlike his usual rupture, was hard and painful. He thought, however, that it must be the rupture and tried to reduce it as usual. This he was unable to do, but he nevertheless applied his truss on top of it and went about his daily work. At first the swelling, though painful, did not cause him any considerable inconvenience, but after a day or two he noticed that it was rapidly growing larger and at the same time the aching pain "as though something were gripping him hard" became so severe that he was unable to get about at all. On the next night (May 4th) be called in a medical man who, after attempting reduction without success, advised the patient to come to the Radcliffe Infirmary as soon as possible.

On admission the patient appeared to be somewhat anæmic. He was a man of a rather unhealthy appearance. His tongue was dry and clean and it was noticed that the lower parts of his abdomen and his thighs were deeply pigmented. Vomiting had not occurred and his bowels had been moved regularly throughout his illness. His temperature was $99^{\circ} \mathrm{F}$. On inspecting the right inguinal region a considerable amount of swelling was observed running down into the scrotum, the skin overlying it was healthy, and no visible impulse was detected on conghing. On palpating the tumour it was found to be very hard, elongated and oval in shape, and about three inches by one inch in size. Its surface was smooth and the mass could be traced from the internal ring down the canal as far as the testicle. It was exquisitely tender to the touch. Percussion only showed that the swelling produced a dull note and nothing could be made out by rectal examination. On May 6th Mr. R. H. A. Whitelocke exposed the tumour by an incision made over the swelling. A small quantity of clear straw-coloured fluid exuded on pricking the sac, and on further opening the mass a rough-walled cavity was laid bare containing a dark red elongated mass. Some purulent material was found, and on lifting up the red mass a clove was discovered lying beneath it. It was then realised that the tumour consisted of a short but very greatly thickened appendix lying in a hernial sac, and accordingly it was removed and the stump cauterised with pure carbolic acid and buried. No other viscus was found to be present in the sac.

It is curious and interesting to note that the patient affirmed that he had not tasted cloves in his food for some time. the last occasion being about a month before his admission, when he remembered having eloves in an apple pudding. Nevertheless, the clove, when removed, was found to be well preserved, the antiseptic action of its essential oils having probably protected it from decomposition. It was in every respect complete, with the exception of one division of the calyx, which was knocked off during the operation, and a little soft and swollen as might have been expected.

We have to express our thanks to $\mathrm{Mr}$. Whitelocke for permission to publish the notes of this case, which appears to be of interest, first, because of the difficulty of diagnosis, for the tumour felt almost like a malignant mass, and yet it had come down so suddenly; secondly, because of the unusual cause-a clove; and thirdly, in that the appendix. greatly thickened and inflamed, was the sole viscus in the sac.

\section{A RECORD OF THE PHYSICAL EXAMINA- TION OF 1000 BOYS AT THEIR ENTRANCE ON PUBLIC SCHOOL LIFE. ${ }^{1}$}

BY CLEMENT DUKES, M.D., B.S. LOND., F.R.C.P. LOND., J.P., PHYSICIAN TO RUGBY SCHOOL.

BY the courtesy of the headmaster of Rugby School I am permitted to submit to the International Congress of School Hygiene the results of the physical examination of 1000 boys on admission to a public school between the ages of 13 and 15 years. These British boys may be regarded as a special class: strong and healthy, wellbred, well-fed, and reared mainly in the country. For oven where in some instances their infancy and childhood were passed in towns and cities, the period of life from the age of 9 to 13 years was usually spent in the country at admirable preparatory schools. The record is entirely free from selection. The examinations were made as the boys severally entered the school and were solely intended to serve as a basis for regulating each boy's physical welfare during his secondary school life by detailing minutely his exact physical state and thereby affording a sure guide to the masters in the appropriate course of education, and for determining the physical exercise and games suitable to each boy's constitution and vigour.

Prior to registering the result of the examinations I drew up a schedule for recording the proposed analysis of $\mathrm{my}$ observations and submitted it to the Editor of THE LANCET with a request that he would refer the form to experts for suggestions tending to its completeness for its purpose. He replied :- "I have submitted your Physical Examination Chart to the author of the leading article in THE LANCET and to one other gentleman taking particular interest in anthropometry. Neither has any suggestion to make. They consider the chart to cover the ground entirely." I insert a copy of the scheme:-

$$
\mathbf{N}=\text { Normal. } \quad \text { Private and Confidential. }
$$

PHYSICAL EXAMINATION.

\begin{tabular}{|c|c|c|c|c|c|}
\hline \multicolumn{4}{|c|}{ I.-NAME } & \multicolumn{2}{|c|}{ Date. } \\
\hline II. $-A G E$. & $\begin{array}{l}\text { In } \\
\text { Height. } \\
\text { Average .. }\end{array}$ & ches. & $\begin{array}{l}\text { lb. } \\
\text { Weight. } \\
\text { Average........... }\end{array}$ & $\begin{array}{r}\text { Che } \\
\text { Measure } \\
\text { Average }\end{array}$ & 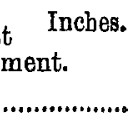 \\
\hline $\begin{array}{l}\text { III.-GENERAL } \\
\text { APPEARANCE. }\end{array}$ & $\left\{\begin{array}{l}\text { 1. Aspect } \\
\text { 2. Physiqu } \\
\text { 3. Nutriti }\end{array}\right.$ & $\begin{array}{l}\text { b. } \mathbf{P} \\
\text { c. } \mathrm{B}\end{array}$ & $\begin{array}{l}\text { Lateral curva } \\
\text { ture of spine... }\end{array}$ & 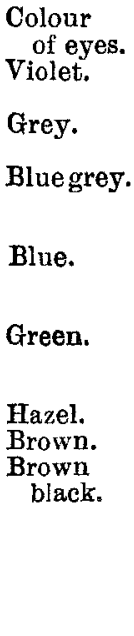 & $\begin{array}{l}\begin{array}{c}\text { Colour } \\
\text { of hair. } \\
\text { Albino. } \\
\text { Very fair. } \\
\text { Fair. } \\
\text { Light } \\
\text { brown. } \\
\text { Brown. } \\
\begin{array}{c}\text { Dark } \\
\text { brown. }\end{array} \\
\text { Black } \\
\text { brown. }\end{array} \\
\text { Black. } \\
\text { Red } \\
\text { brown. } \\
\text { Dark red. } \\
\text { Red. } \\
\text { Golden. } \\
\text { Light red }\end{array}$ \\
\hline
\end{tabular}

1 A paper read before the Second International Congress of School Hygiene, held at the University of London, August 5th-10th, 1907. 


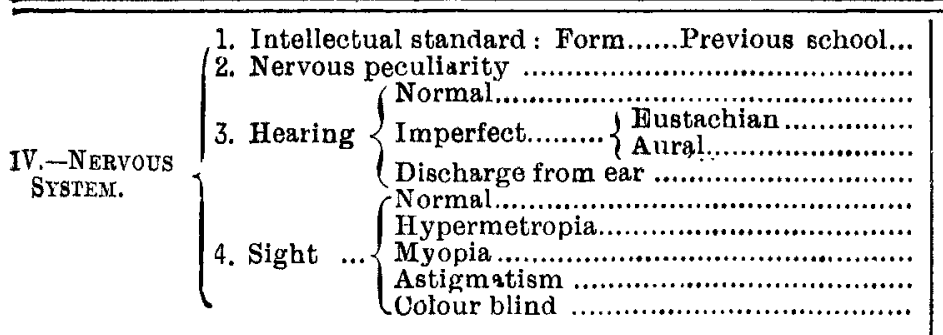

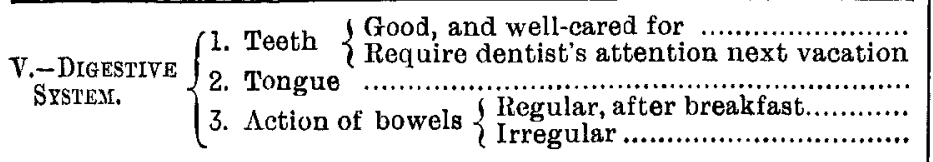

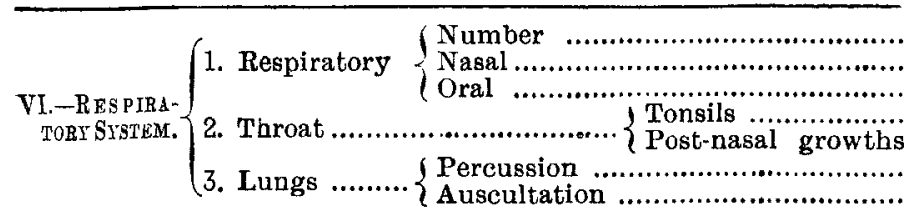

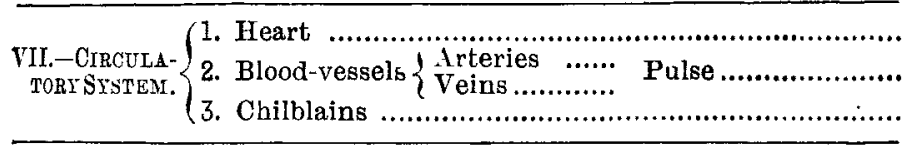

\begin{tabular}{|c|c|}
\hline VIII,-GenITO- & 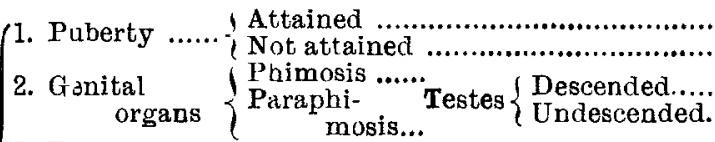 \\
\hline URINARY & 3. Rupture............... \\
\hline SYSREM. & 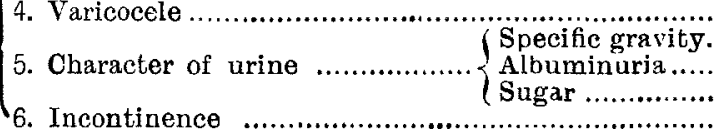 \\
\hline
\end{tabular}

\begin{tabular}{l} 
IX.-PRejlous IMPORTANT \\
ILLNESSES. \\
\hline
\end{tabular}

\section{X.-IMPORTANT ILLYMESSES}

AT SCHOOL.

Signed............................................

SCHOOL GAMES.

Adapted to ........................................................

$O$ Not to play. $X$ Mar play. $X X$ Ought to be made to play. $X X X$ No restrictions.

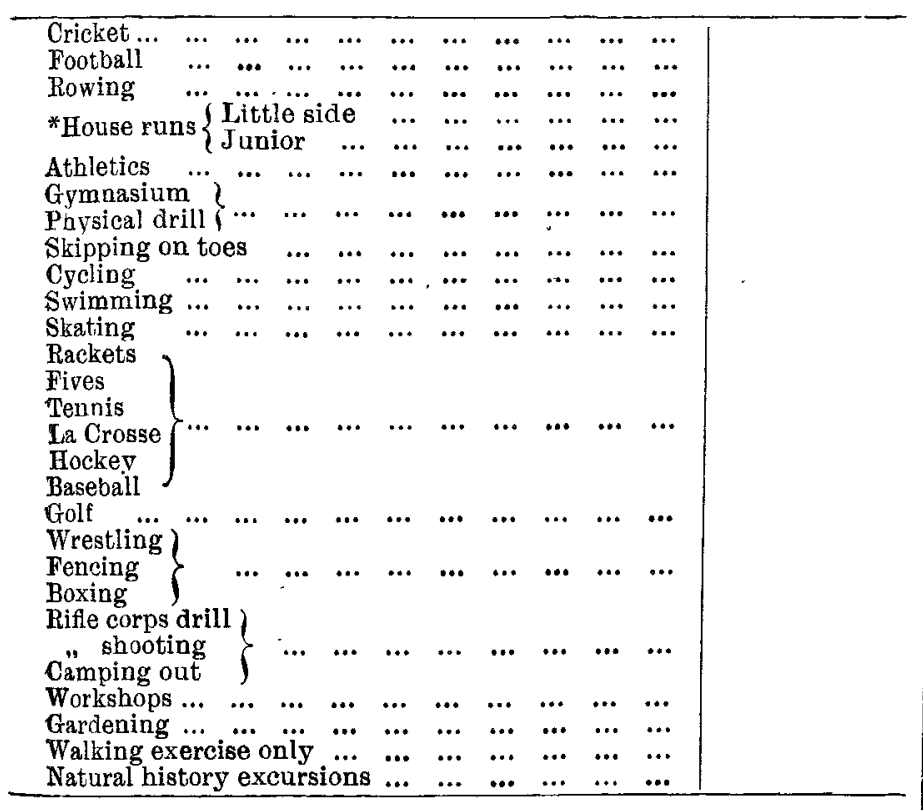

\section{Signed ............................................}

* No physician can certify that the boy can run, although he may sometimes be able to say that he cannot.

As soon as it is clear to the captain in charge that the boy can run Ass soon as it is elear to the captain in charge that the boy can run
his welfare in every respect.

N.B.-Appropriate space is required to insert the details of the N.B. -Appropt
examination.

The record commenced on Jan. 21st, 1899, and was completed on May 6th, 1907. I have begun to tabulate a second thousand entries, which I hope will ${ }_{5}$ be similarly concluded by other hands than mine.

Height, Weight, and Chest Measurements.

It would be of considerable interest were $I$ able to record the annual rate of growth in height, weight, an 1 chest measurements, inasmuch as boys vary greatly in this respect, for some grow slowly before puberty, but make ap for this defect at the age of puberty, or even postpone this increase until the ages of 17 or 18, when they grow enormously. In fact, many boys who develop very gradually at first, both mentally and bodily, outstrip their schoolfellows in both respects towards the end of school-life-some growing -in height at the expense of weight, and vice versâ.

The tables which I have used are those of Mr. Charles Roberts, who is the only author who has recorded, amongst others, the height and weight of public school boys. His table is here appended :-

Table showing the Average and Mean Height and Weight and the Annual Rate of Inorease of $7 \% 09$ Boys and Men, between the Ages of 10 and 30 Years, of the Most Favoured Classes of the knglish Population-Public-sohool Boys, Naval and Military Cadets, Medical and University Students.

\begin{tabular}{c|c|c|c|c|c|c|c|c}
\hline & \multicolumn{2}{|c|}{} & \multicolumn{3}{|c|}{ Weight, including clothes } \\
of ylb.
\end{tabular}

The record of the height, weight, and girth is of inestimable value to the master who, possessing this chart, on which are also prescribed the suitable physical training and games for every "new boy" admitted, is thus intelligently and efficiently enabled to provide for his appropriate individual rearing during the period of education. At some future date these registers of height, weight, and girth should be subjected to minute analysis and classification, for they contain indiscriminately the cases of boys of excessive height with defective weight and of diminished growth with abnormal weight. This necessary analysis, however, must be undertaken by others who have more leisure at their disposal than I can command, as well as greater ingenuity in the handling of figures. The circumference of the chest, measured on the bare skin at the nipple-line, expresses the capacity of the lungs on deep inspiration and expiration. This respiratory capacity has a wide range, varying from one inch to five inches.

In specifying the numbers throughout this paper it must be recollected for the purpose of avoiding continuous repetition that they are all in relation to the standard of 1000 .

$$
\begin{aligned}
& \text { Height } \ldots . . \ldots \quad \ldots\left\{\begin{array}{llllll}
\text { Above normal } & \ldots & \ldots & \ldots & 522 \\
\text { Average } & \ldots & \ldots & \ldots & \ldots & 113 \\
\text { Below }
\end{array}\right. \\
& \left\{\begin{array}{llllll}
\text { Average } & \ldots & \ldots & \ldots & \ldots & 113 \\
\text { Below normal } & \ldots & \ldots & \ldots & 365
\end{array}\right. \\
& \text { Weight ... } \quad \ldots . . .\left\{\begin{array}{lllllr}
\text { Above normal } & \ldots & \ldots & \ldots & 472 \\
\text { Average } & \ldots & \ldots & \ldots & \ldots & 57 \\
\text { Below } & \ldots & \ldots &
\end{array}\right.
\end{aligned}
$$

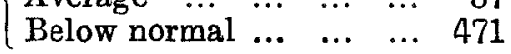

$$
\begin{aligned}
& \text { (Above normal ... } \ldots . . \ldots \quad 445
\end{aligned}
$$

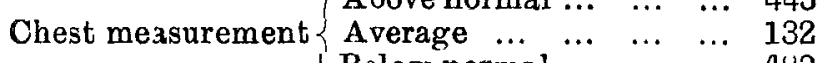

$$
\begin{aligned}
& \text { (Below normal ... ... ... } 423 \\
& \text { Deformities. }
\end{aligned}
$$

It is necessary to state in limine that in no instance were slight defects registered, but only such as were of sufficient practical importance to the sufferer to need special attention 
at the hands of the drill-sergeant or the gymnasium instructor.

It is somewhat depressing to register in the twentieth oentury the large number of acquired preventable deformities (not momentous, it is true, but still indicative of inferior systems of nurture and education) which are presented by the most favoured class of boys in Great Britain - deformities occurring between the time of nursery-life and the com. pletion of education in the preparatory school at the age of 13 Some of these infirmities arise from faults in nutrition during infancy, which entail rickets. And these defects in nutrition, as a canse, tend at the present day to involve the children of the rich even more than those of the poor in their sequent physical evils. For a preponderating proportion of mothers in the higher social rank either cannot, or will not, nurse their children; and more than this, substitate for the naturally-appointed breast-milk, boiled cows' milk, which, in the process of boiling, is deprived of some element in its nutritive value which tends to the advent of rickets or infantile scurvy. Also resort is made to various artificial foods, equally insufficient for the adequate nourishment of infants in their earliest months of life. On the other hand, some of these deformities may result from the debilitating effects of infantile maladies, while the remainder are incidental to unnatural school methods and the disfiguring effect produced by faulty postures, permitted or practically compelled during school-life, so that the supple bones kecome moulded imperceptibly, but surely, into abnormal forms.

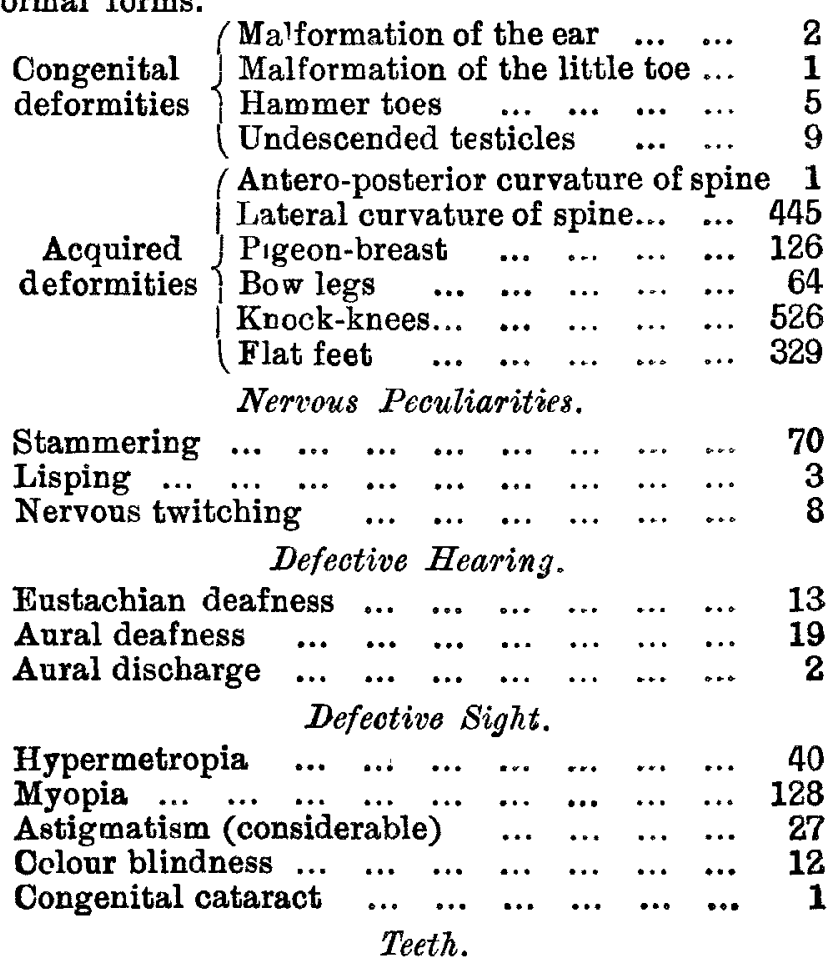

In several instances no decayed tooth was to be observed. In the large proportion of cases the teeth, where decayed, had been carefully attended to by the dentist.

$$
\begin{aligned}
& \text { Teeth } \quad \ldots \quad \ldots\left\{\begin{array}{lllllr}
\text { Well-cared for } & \ldots & \ldots & \ldots & 943 \\
\text { Neglected } & \ldots & \ldots & \ldots & \ldots & 57
\end{array}\right. \\
& \text { Respiration. }
\end{aligned}
$$

In the large proportion of observations the respiration was nasal and in many of these instances operations had already been performed for post-nasal growths. The respiration, where oral, was generally attributable to a very short upper lip, which prevented the mouth from being closed, or to the presence of adenoids.

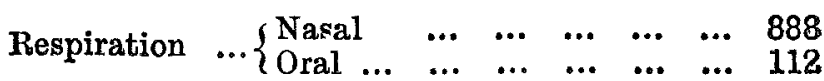

$$
\begin{aligned}
& \text { Heart Disease. } \\
& \text { Heart disease }\left\{\begin{array}{lllllll}
\text { Mitral } & \ldots & \ldots & \ldots & \ldots & \ldots & 8 \\
\text { Aortic } & \ldots & \ldots & \ldots & \ldots & \ldots & 1 \\
\text { Irregular action } & \text { of } & \text { heart } & \ldots & 1
\end{array}\right.
\end{aligned}
$$$$
\text { Chilblains. }
$$

These vary greatly, some being of a trivial character, while others entail much suffering when they reach the stage of "broken chilblains." The chief sufferers are those of a florid complexion, which usually signifies atony of the vaso-motor system, and a still larger propcrtion suffer from the albuminuria of adolescents. $\begin{array}{lllllll}\text { Sufferers from chilblains } & \ldots & \ldots & \ldots & \ldots & \ldots & 437\end{array}$

\section{Hernia.}

Hernia $\ldots\left\{\begin{array}{l}\text { Inguinal congenital } \\ \text { Umbilical }\end{array}\right.$

Varicocele.

Varicocele $\ldots . . .\left\{\begin{array}{llllllr}\text { Right } & \ldots & \ldots & \ldots & \ldots & \ldots & 4 \\ \text { Left } & \ldots & \ldots & \ldots & \ldots & \ldots & 92\end{array}\right.$

Urinary System.

The number of instances of albuminuria is somewhat startling to those who have not devoted special attention to the subject at early ages; but this functional disturbance is not of serious importance. Amongst those who were known to have this ailment during school life I have never once found the condition existent when they had arrived at maturity. While the malady is largely dependent upon the state of the vaso-motor system, it is also subject to some condition of the blood, inasmuch as Sir A E. Wright has shown incontestably that it is at once removed by supplying the blood with lime salts either in the form of an abundance of milk (which contains a large amount of lime) or by the administration of lactate of lime. In the interests of the growth, development, and happiness of boys at school, therefore, I would once again urge the importance of not placing lads exhibiting this condition upon a restricted diet and, as is so frequently and needlessly done, prohibitinggames within reason, since experience has proved that these. regulations are not consistent with their welfare.

$$
\begin{aligned}
& \text { Incontinence of urine }\left\{\begin{array}{llllr}
\text { Diurnal } & \ldots & \ldots & \ldots & 2 \\
\text { Noctarnal } & \ldots & \ldots & \ldots & 26
\end{array}\right.
\end{aligned}
$$

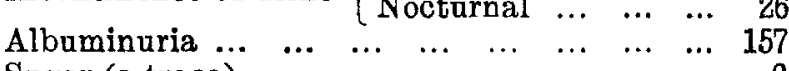

$$
\begin{aligned}
& \begin{array}{lllllllll}
\text { Sugar (a trace) } & \ldots & \ldots & \ldots & \ldots & \ldots & \ldots & \ldots & 3
\end{array} \\
& \text { Puberty. }
\end{aligned}
$$

Occasionally a boy has entered school as young as the age of $12 \cdot 75$, and once a boy came as late as $16 \cdot 75$; but in all other cases the age of entrance was between 13 and 15 years. Between these years 317 had already attained the stage of puberty ; while, however, many have reached puberty at 13 , its advent in a few cases has been deferred until after the age of 15 .

Rugby.

\section{A CASE OF TYPHOID FEVER : A NOTE ON THE BACTERIOLOGICAL FXAMINATION OF THE BLOOD.}

BY WINIFRED MUIRHEAD, L.R.C.P., L.R.C.S.EDIN. ASSISTANT MEDICAL OFFICER, STIRLING DISTRICT ASYLUM, LARBERT, N.B.

IN THE LANCET of July $27 \mathrm{th}^{\mathrm{l}}$ there is a note on a paper published by Dr. W. Coleman and Dr. R. H. Buxton on the subject of bacteriological examination of the blood in typhoid fever; it appeared to me of interest to record the following case:-

In March last a female patient was admitted to the

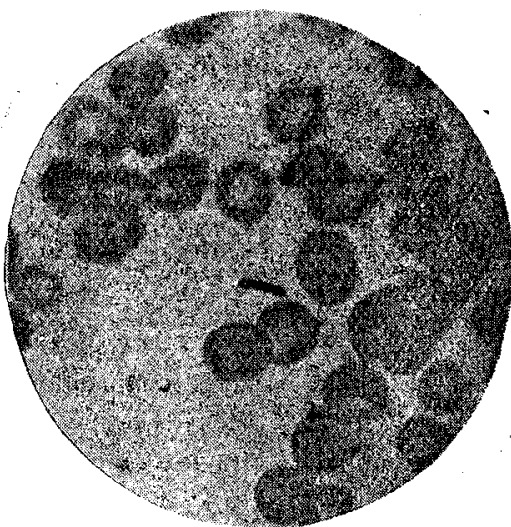

Blood film, showing bacillus typhosus.

asylum suffering from acnte delirious insanity with a history of illness ten days in duration. Her mental condition was one of great excitement and confusion, with hallucinations of sight and hearing. Physically the patient was found to have an enlarged and palpable spleen, discrete 